\title{
Title: 3D bioprinting for musculoskeletal applications
}

\begin{abstract}
This review focuses on developments in the field of bioprinting for musculoskeletal tissue engineering, along with discussion on the various approaches for bone, cartilage and connective tissue fabrication. All approaches (cell-laden, cell-free and a combination of both) aim to obtain a complex, living tissues able to develop and mature, using the same fundamental technology. To date, co-printing of cell-laden and cell-free materials has been revealed to be the most promising approach for musculoskeletal applications because materials with good bioactivity and good mechanical strength can be combined within the same constructs. Bioprinting for musculoskeletal applications is a developing field, and detailed discussion on the current challenges and future perspectives is also presented in this review.
\end{abstract}

Keywords: 3D bioprinting, biofabrication, bioinks, biomaterials, tissue engineering, organ printing, bone, cartilage, musculoskeletal tissue fabrication

Financial Disclosure: None of the authors have any commercial associations or financial relationships that would create a conflict of interest with the work presented in this article. 


\section{Introduction}

Every 30 seconds, a patient dies from a condition that could be treated with organ replacement [1]. Organ transplantation has potential to be an efficient solution but is restricted due limited donor availability. Furthermore, organ transplantation requires complex surgical interventions and can lead to complications, such as organ dysfunction or rejection. Successful translation of tissue engineering and regenerative medicine research is key to alleviating the challenges in organ transplantation, but can also be applied to disease modelling and drug discovery (Figure 1). More specifically, improved understanding of the biological architecture and natural repair processes in adult tissues could aid the challenging fabrication of de novo organs, for these applications. For cells to self-assemble into tissues, they need an environment in which cells can remain viable and are able to adhere and migrate. The most important factors to consider are growth factors, nutrients, adhesion molecules, cells, materials and the technologies applied to enhance the fabrication process [2]. This review focuses on developments in bioprinting for musculoskeletal tissue engineering, and provides discussion on the various approaches for bone, cartilage and connective tissue fabrication, along with current challenges and future perspectives.

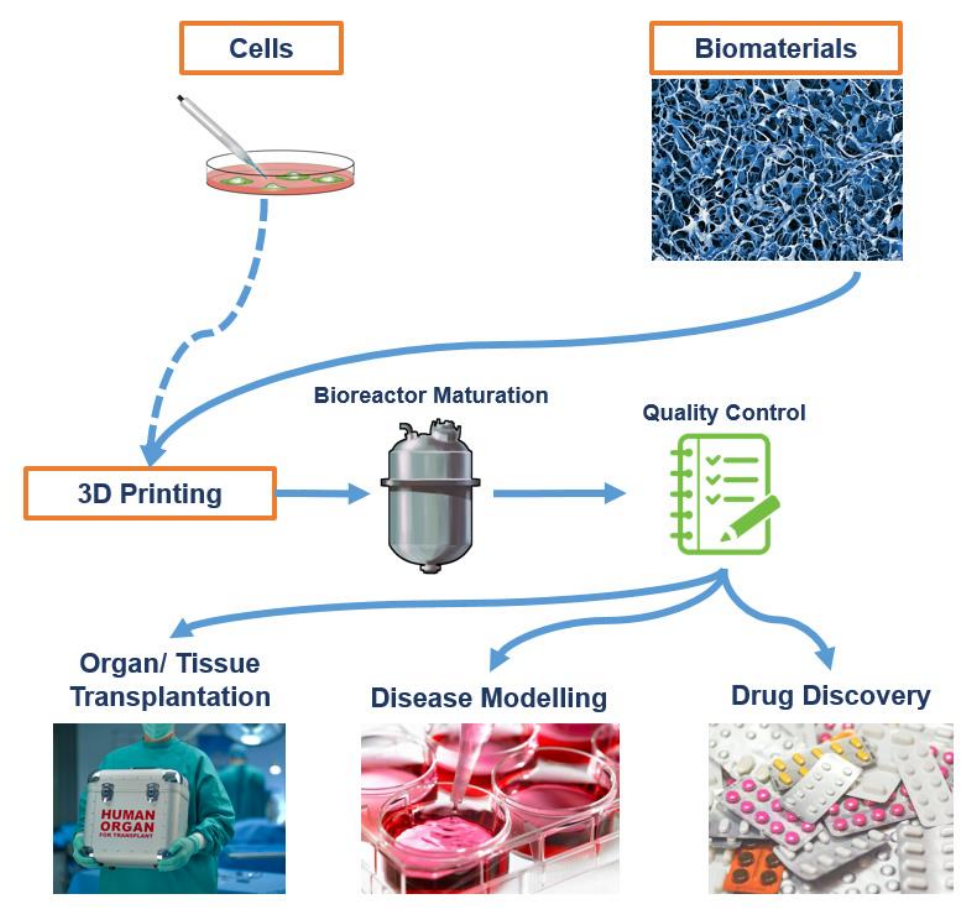

Figure 1. Translating tissue engineering and regenerative medicine research into healthcare applications for the future, including organ/ tissue transplantation, disease modelling and drug discovery. 


\section{Bioprinting and its role in musculoskeletal tissue fabrication}

The musculoskeletal system (MSK) provides structural support for the body and comprises of vital tissue components such as bone, cartilage, muscles, tendons and ligaments. When these tissues are damaged through injury, their repair remains challenging due to their limited regenerative potential.

Every year, over 2 million bone grafts are performed worldwide, due to diseases, sarcomas, or trauma injuries [3]. In the US, musculoskeletal injuries reach 32 million per year, of which, $45 \%$ are represented by tendon, ligament, and joint capsular injuries [4]. Autografts are considered as the gold standard procedure for treating small MSK defects due to their compatibility with patients. However, obtaining these grafts causes defects in secondary sites and can delay patient recovery time. Furthermore, autografts contribute additional trauma injury and are limited by size.

For bigger defects, allogenic or biomaterial grafts are used. However, the use of allogenic grafts has several disadvantages including: immune rejection, the necessity for multiple surgical procedures to remove donor material, cost and limited tissue regeneration and revascularisation potential [5]. Synthetic grafts can also inhibit vascularisation and de novo tissue formation [6]. Tissue engineering advances can provide solutions to these problems. Nevertheless, traditional tissue engineering approaches are slow and cannot be used for large scale production of biological matter with the required complexity.

Bioprinting promises fast, on demand, and automated manufacturing of high resolution constructs. The process involves the use of 3D printing technologies to deposit cells or biological factors into predefined shapes and sizes [7]. Bioprinting permits stringent control on placement of cells within matrices and enables the arrangement of biological materials within composite, hierarchical structures and, patterns. This promises new opportunities to fabricate reproducible, patient-specific grafts with low risk of immune rejection. The most popular and promising bioprinting techniques include inkjet and extrusion printing. However, laser-assisted technologies are also in development [7]. Details on the various 3D bioprinting techniques are reported elsewhere [8]. 
To date, several research groups have bioprinted materials and cells for musculoskeletal applications. The two most common approaches used for 3D bioprinting, include the printing of cell-free and cell-laden materials. Tables 1 and $\mathbf{2}$ outline how bone, cartilage, muscle, tendon and ligament tissues have been fabricated using these approaches. Figure 2, summarises the benefits of each approach.

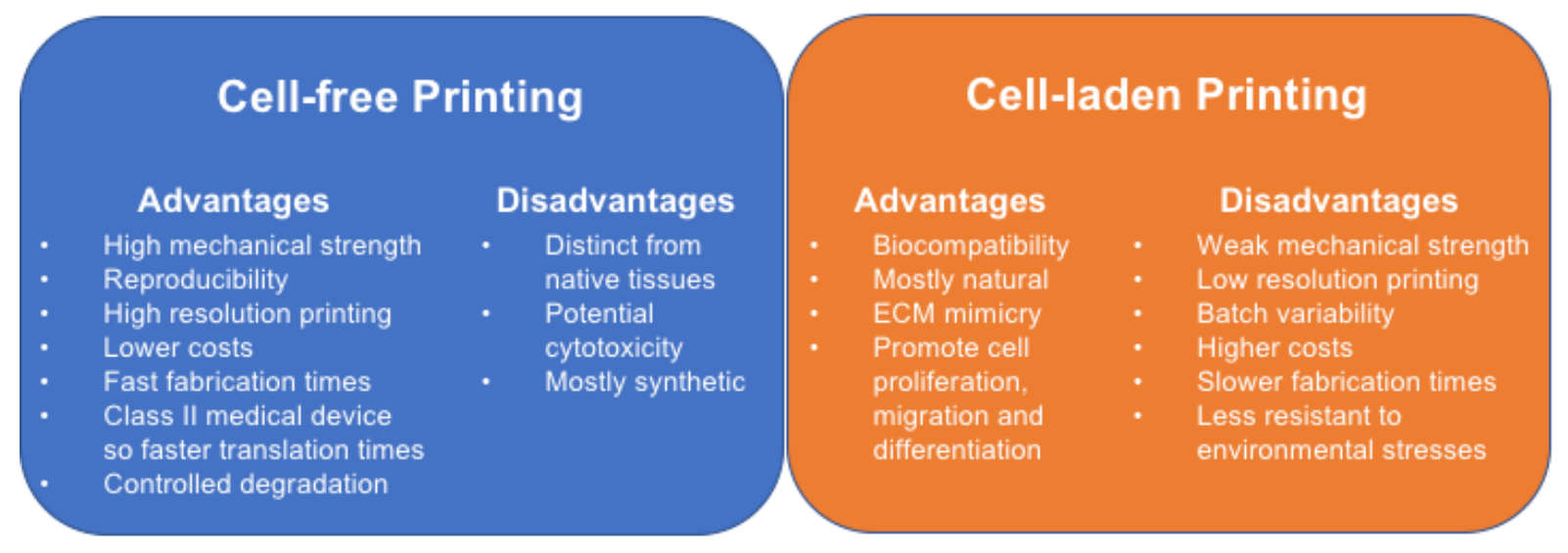

Figure 2. 3D printing approaches for musculoskeletal tissue fabrication. The advantages and disadvantages of cell-free or cell-laden 3D printing.

The current literature suggests that synthetic materials are more widespread for cell-free printing, while natural polymers have been commonly combined with cells, prior to extrusion. To evaluate the most popular approaches and materials used for bioprinting of musculoskeletal tissues, we reviewed the literature published in this area during the last 15 years. Figure 3 summarises the various materials used for 3D printing using cell-free and cell-laden approaches in MSK tissue engineering. The data suggests that around $84 \%$ of the materials used for cellfree printing are synthetic. This is primarily because these materials provide the strong mechanical properties required for musculoskeletal applications. The remaining $16 \%$ of articles show feasibility of this cell-free approach using natural materials (such as collagen, alginate) and this can be due to their higher biocompatibility compared to synthetic materials. One good example of cell-free printing for bone repair focussed on composite scaffold printing, where PCL-hydroxyapatite-carbon nanotubes were printed with pores in the range of 450-700 $\mu \mathrm{m}$ (Figure 4) [9] ${ }^{*}$. Results show that a $4 \mathrm{MPa}$ compressive strength was obtained and this is analogous to trabecular bone. The composite scaffolds also exhibited enhanced cell adhesion and improved hydroxyapatite bioactivity, when seeded with MG63 osteoblast-like cells. Nevertheless, the materials were distinct from native bone due to the presence of PCL and 
carbon nanotubes, and the cells were seeded in a traditional engineering approach. This led to uneven cell seeding/ distribution.

A

\section{Cell-free Printing}

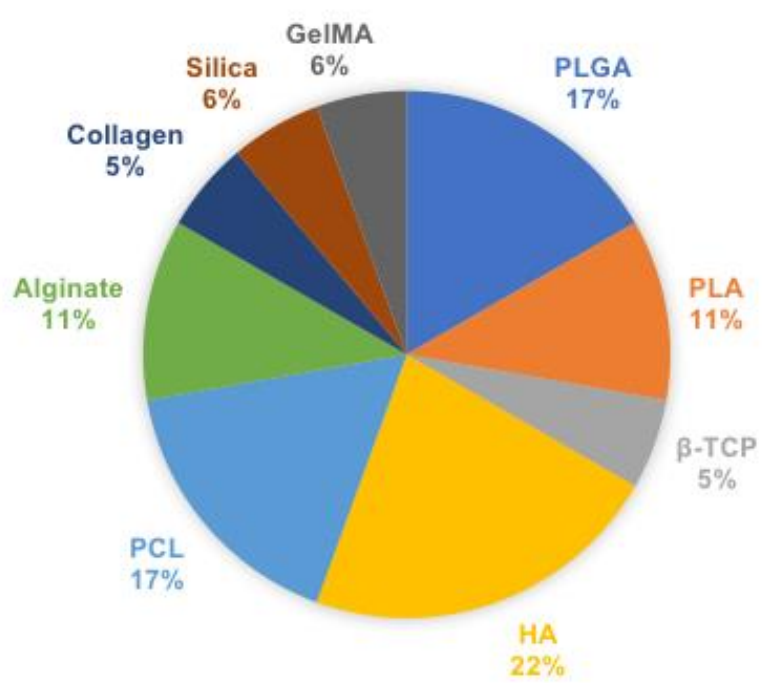

B Cell-laden Printing

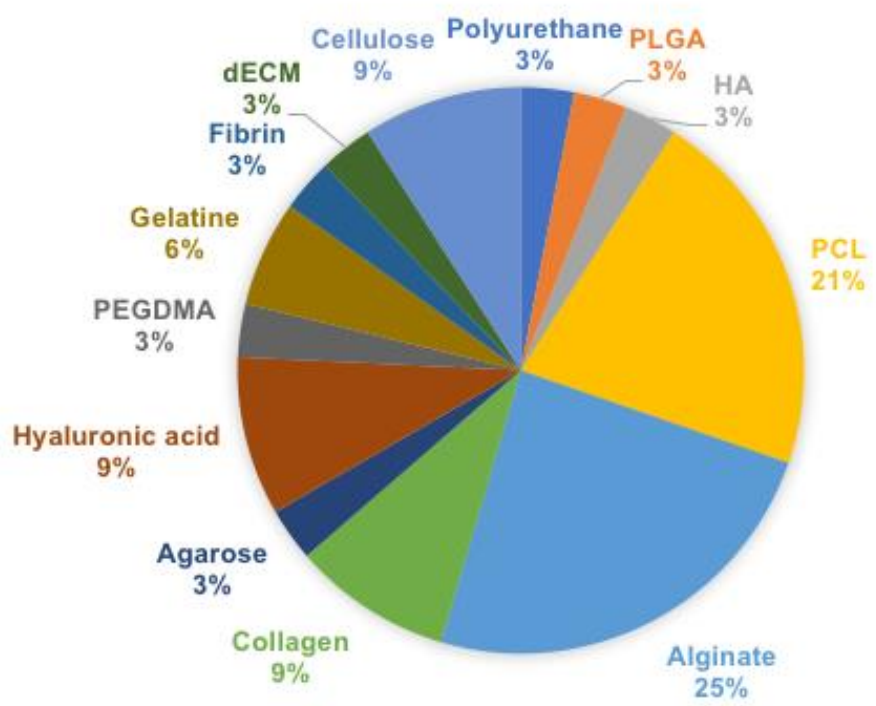

Figure 3. Percentage of various materials used in A) cell-free and (B) cell-laden printing for musculoskeletal applications. The data is based on articles published in the last 15 years using the search terms "3D printing", "bioprinting" and "bioink" associated with "bone", "cartilage", "osteochondral", "muscle", "tendon" and "ligament".

In the literature, naturally-derived biomaterials such as alginate [10,11], collagen [11], gelatine and fibrin [12], have successfully promoted cell adhesion, proliferation and osteochondral differentiation with both cell-free and cell-laden printing approaches. However, natural 
materials were the most common materials used for cell-laden printing ( $70 \%$ of total reported in literature, Fig 3B) for musculoskeletal applications. This is predominantly because of their capacity to form gels that can support cell encapsulation and survival during the $3 \mathrm{D}$ printing process.
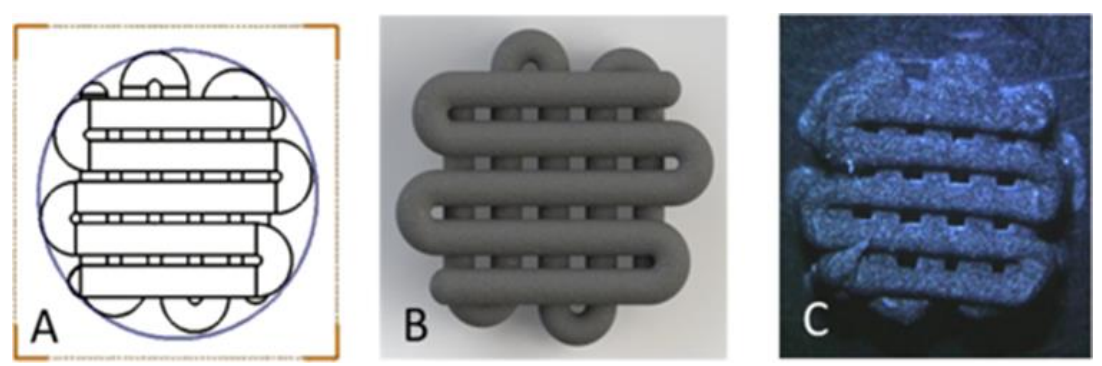

Figure 4. Structural properties of PCL-hydroxyapatite composites strengthened with carbon nanotubes for bone repair. (A) Technical drawing, (B) 3D simulation and (C) printed 3D scaffold with square pores. Image adapted with permission from [9].

Due to their poor mechanical properties, some of these natural biomaterials have been coprinted with other synthetic polymers for musculoskeletal applications. This can be realised by using multi-tool printing, which requires special modifications to printers, such as incorporation of additional print heads or extruders. Daly et al. used multi-tool printing to produce a mechanically reinforced cartilaginous template mimicking the geometry of a vertebral disk [13]. In this approach developmental precursors to an adult organ were bioprinted and the engineered construct functioned as a template for subsequent organogenesis in vivo. This was achieved by printing a PCL template, followed by the deposition of a RGDalginate hydrogel laden with adult stem cells, as shown in Figure 5. When implanted into a mouse model, the resultant bioprinted construct supported the development of vascularised bone containing trabecular-like endochondral bone with a supporting marrow structure. 


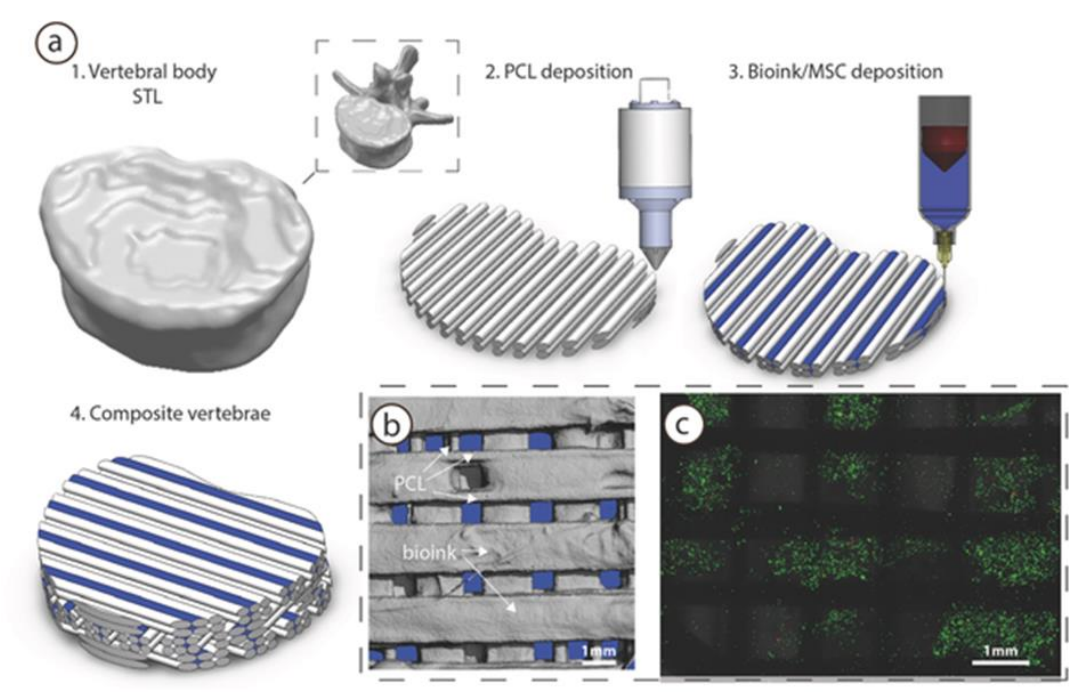

Figure 5. Bioprinting of vertebrae-shaped bioinks with enhanced mechanical properties for bone regeneration. (A) Multi-tool 3D printing was applied to produce a composite vertebrae structure by depositing PCL filaments followed by an MSC-laden bioink (RGD-alginate). (B) MicroCT analysis to illustrate the distribution of the bioink and PCL. (C) Live/ dead images of MSCs within the bioprinted vertebrae. Image taken with permission from [13].

In another example using multi-tool printing, the vascularised bone was engineered when PLA was deposited with FDM printing technology, while GelMA containing BMP and VEGF was co-printed using SLA [14]**. This study demonstrated that the dual 3D printed constructs provided a hierarchically biomimetic bone-like structure, with multiphasic characteristics and potential for vascularised bone regeneration, as shown in Figure 6. This is a noteworthy approach to produce complex tissue structures in the lab. However, it is important to stringently assess the functionality of this vascularised bone and make quantitative comparisons with native tissues.

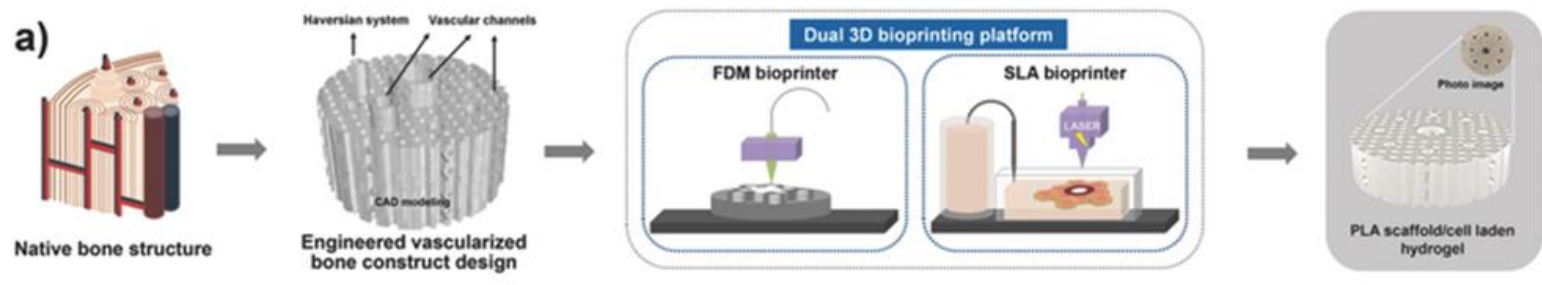

Figure 6. Production of engineered vascularised bone via 3D printing. Schematic illustration of the biomimetic architectural design and hierarchical fabrication process for printing of biphasic vascularised bone constructs using a FDM/ SLA platform. Image taken with permission from [14]. 
In addition to this work, interesting results have been obtained using synthetic materials. Poly (ethylene glycol) dimethyl acrylate (PEG-GelMA) was successfully inkjet printed with human chondrocytes for the repair of small osteochondral defects [15]. In another study, bone and cartilage tissues were fabricated through inkjet printing of human mesenchymal stem cells and, simultaneous deposition and photo-crosslinking of PEG-GelMA [16]. Others have achieved minimal print-head clogging by printing acrylate peptides and PEG hydrogels with human mesenchymal stem cells to promote robust bone and cartilage formation [17]. Porous bioactive glass/ alginate composite scaffolds have also been fabricated for bone tissue engineering using 3D printing [18].

As a prospective treatment for cartilage lesions, recent study reported use of 3D bioprinting approach to form cartilage mimetics using a nano-fibrillated cellulose and alginate-based composite bioink seeded with human-derived induced pluripotent stem cells (iPSCs) and human chondrocytes [19]. The bioprinted constructs could maintain pluripotency initially, and after five weeks, hyaline-like cartilaginous tissue with collagen type II expression, lacking tumorigenic OCT4 expression was observed. Furthermore, a significant increase in cell number within the cartilaginous tissue was detected. This study combines 3D printing and stem cell technology to generate viable tissues for clinical applications.

While the majority of studies focus on bone and cartilage regeneration, recent work has shown progress in the bioprinting of other musculoskeletal tissues, such as muscles and tendons. An Integrated Tissue-Organ Printer (ITOP) was used for the fabrication of skeletal muscle structures. The approach was based on the printing of well-defined PCL patterns for directional alignment of the muscle cells, as shown in Figure 7. At the same time, cells were deposited using a mixture of hydrogels (gelatine, hyaluronic acid and fibrinogen), which were loaded with mouse myoblasts cells. Results showed good cell viability, and alignment along the PCL pillars/ patterns and muscle-like structures were observed after 7 days. When the constructs were implanted in vivo, they integrated with the common peroneal nerve (CPN) after 2 weeks and the muscle was seen to respond to electrical stimuli [20]. Even though bioprinting examples in this area are limited, this study provides good evidence that $3 \mathrm{D}$ printing can be used for the development of various fibrous tissues (muscle, tendon and ligament) where cellular alignment is a key requirement [21]. 

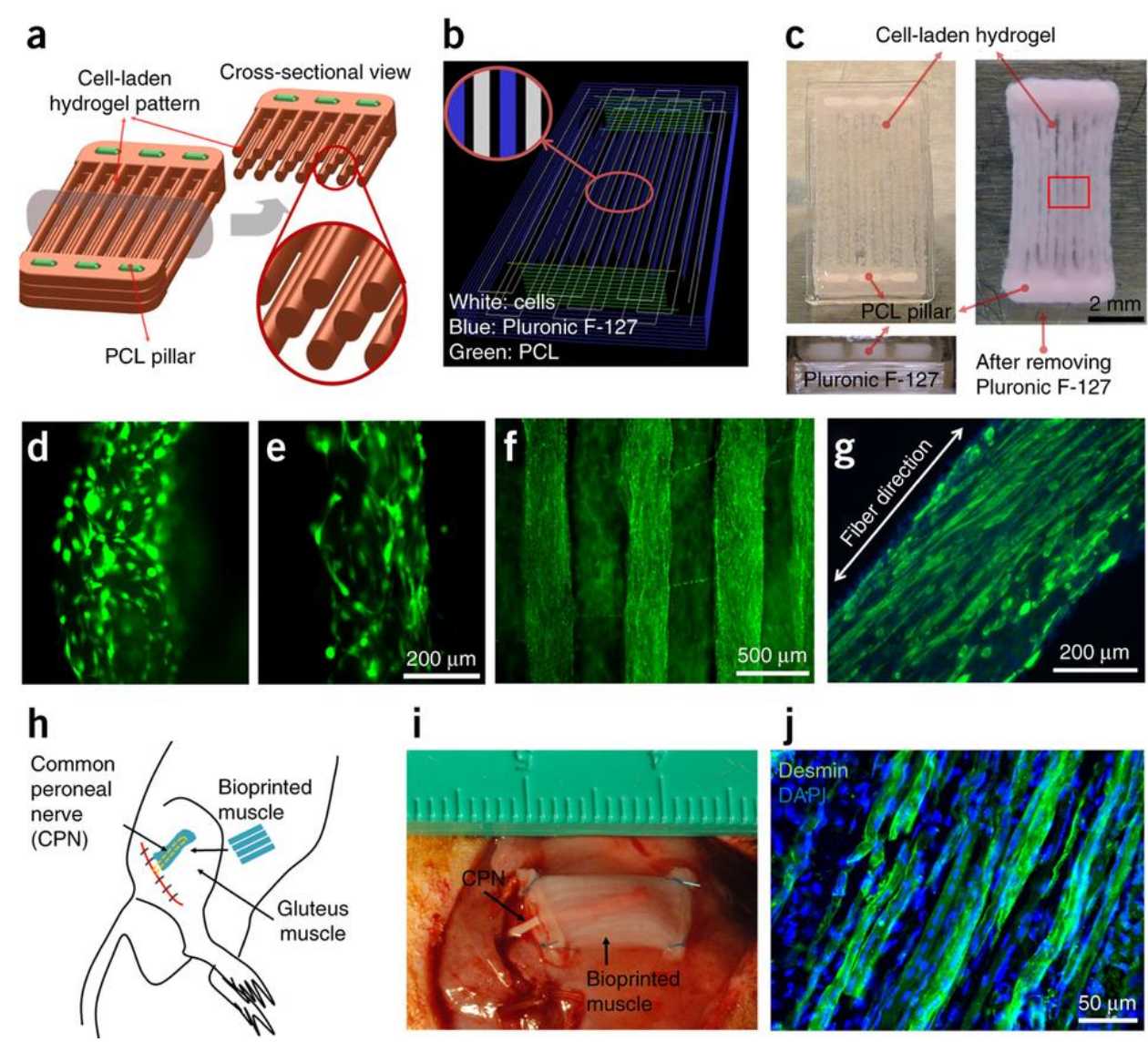

Figure 7. Bioprinting of skeletal muscle and implantation in vivo. (A) and (B) scaffold design; (C) scaffold fabrication; cell alignment with PCL (D) and without PCL (E); F) Live/ dead assay: green cells are alive and red cells are dead; (G) Immunofluorescent staining for myosin heavy chain of the 3D printed muscle after 7D differentiation. The encapsulated myoblasts aligned along the longitudinal direction of the fibre structure; $(\mathrm{H})$ schematic of the ectopic implanted scaffold in vivo; (I) implanted scaffold next to the common peroneal nerve (CPN) and (J) immunostaining for Desmin. Adapted from [20] with permission from Nature publishing group.

While various materials have been used as bioinks for printing cell-free and cell-laden constructs, cells alone in the form of tissue spheroids have also been investigated for 3D bioprinting. Printed cells have a fluid nature and over time, they fuse together to form more complex cell aggregates that can potentially lead to tissue formation [22]. In the literature, tissue spheroids have already been successfully used for cartilage tissue engineering [23-25]. However, successful production of constructs using tissue spheroids is still in its infancy and focus needs to be applied on utilising 3D printing technologies to help with scale-up, reproducibility and formation of more complex structures [26,27]. 
Breakdown of the materials used as bioinks for bone and cartilage bioprinting in the last 15 years, show some interesting trends. The majority of all the cell-free approaches used materials such as PCL, $\beta$-TCP or hydroxyapatite (Figure 3). In contrast, alginate was the most popular material for cell-laden bioinks (25\%) and this was followed by PCL (21\%) and collagen (9\%). Alginate was applied due to its good printability, while PCL is a biocompatible mechanical strength enhancer of the cell-laden hydrogels. Notably, there is greater variety in the materials used for cell-laden printing than cell-free printing.

3D printing has been successfully applied in a variety of ways to address the growing demand for more robust musculoskeletal therapies. Nevertheless, the use of the technology for medical purposes is still in its infancy. There is need for further research and development in both 3D printing technology and bio-ink formulations for successful translation of this technology in future. 


\begin{tabular}{|c|c|c|c|c|c|c|c|}
\hline Biomaterials & Cells & $\begin{array}{l}\text { Printing } \\
\text { Technique }\end{array}$ & Application & Construct Morphology & Mechanical Properties & Advantages (A)/ Disadvantages (D) & Reference \\
\hline $\begin{array}{l}\text { PLGA + PLA } \\
\text { (cartilage) and PLGA + } \\
\text { tricalcium phosphate } \\
\text { (TCP) (bone) with } \\
\text { gradients at interface }\end{array}$ & $\begin{array}{l}\text { Ovine Articular } \\
\text { Chondrocytes }\end{array}$ & $\begin{array}{l}\text { Inkjet: } \\
\text { TheriForm }^{\text {TM }}\end{array}$ & Osteochondral & $\begin{array}{l}3 \text { regions: } 4 \mathrm{~mm} \text { cloverleaf bone } \\
\text { region with } 55 \% \text { porosity, } 1.2 \\
\mathrm{~mm} \text { transition region with three } \\
\text { gradient sections } 2 \mathrm{~mm} \\
\text { cartilaginous region with } 90 \% \\
\text { porosity and staggered } 250 \mu \mathrm{m} \\
\text { channels. }\end{array}$ & $\begin{array}{l}\text { Tensile data: a. tensile strength 1.6-5.7 MPa } \\
\text { b. elastic modulus 83-233 MPa } \\
\text { Compressive data: a. yield strength } 2.5-13.7 \\
\text { b. elastic modulus 54-450 MPa } \\
\text { Diameter shrinkage: cartilage region } 8.3 \% \text { and } \\
\text { adjacent transition zones 3.8\% }\end{array}$ & $\begin{array}{l}\text { A: Homogeneous cell seeding (material gradients at the } \\
\text { interface) and no delamination. } \\
\text { D: Compressive properties of the bone region of the construct } \\
\text { are lower than those of cancellous bone. }\end{array}$ & [28] \\
\hline Hydroxyapatite (HA) & $\begin{array}{l}\text { Mouse Pre- } \\
\text { Osteoblasts } \\
\text { (MC3T3-E1) }\end{array}$ & $\begin{array}{l}\text { Indirect } \\
\text { writing } \\
\text { (powder + } \\
\text { binding } \\
\text { solution) }\end{array}$ & Cartilage & $\begin{array}{l}\text { Internal structure: walls that all } \\
\text { stand in } 45^{\circ} \text { to the } \mathrm{x} \text {-axis with } \\
1.2 \mathrm{~mm} \text { of distance between } \\
\text { them with } 500 \text { mm } \\
\text { interconnecting channels. }\end{array}$ & $\begin{array}{l}\text { Shrinkage after sintering: } 18-20 \% \text { in all } \\
\text { directions }\end{array}$ & $\begin{array}{l}\text { A: Cells cultured in static and dynamic conditions. Multiple } \\
\text { cell layers on the surface of the HA granules (static) and cell } \\
\text { proliferation inside granule cavities (dynamic). } \\
\text { D: Mechanical properties not evaluated. }\end{array}$ & [29] \\
\hline PLGA & $\begin{array}{l}\text { Human Foetal } \\
\text { Osteoblasts }\end{array}$ & $\begin{array}{l}\text { Inkjet: } \\
\text { ZPrinter } 310 \\
\text { PLUS }^{\mathrm{TM}}\end{array}$ & Bone & $\begin{array}{l}6 \mathrm{~mm} \text { in diameter and } 6 \mathrm{~mm} \text { in } \\
\text { height with interconnected } \\
\text { channels. } 1 \mathrm{~mm} \text { pores and } 55 \% \\
\text { porous. Rough Macro porous } \\
\text { surface. }\end{array}$ & $\begin{array}{l}\text { Compressive strength: } 7.8 \pm 3.1 \mathrm{MPa} \\
\text { Compressive Young's modulus: } 77.2 \pm 10.8 \\
\text { MPa }\end{array}$ & $\begin{array}{l}\text { A: Mechanical properties mimic human cancellous bone and } \\
\text { supports osteoblasts proliferation. } \\
\text { D: Mechanical properties still lower than the ones of human } \\
\text { cortical bone. }\end{array}$ & [30] \\
\hline $\begin{array}{l}\mathrm{PCL} / \mathrm{HA} \text { (shifted } \\
\text { pattern) }\end{array}$ & $\begin{array}{l}\text { Human } \\
\text { Osteosarcoma } \\
\text { (MG 63) }\end{array}$ & Bioplotter & Bone & $\begin{array}{l}5 \times 5 \times 5 \mathrm{~mm}^{3} \text { scaffolds. Square } \\
\text { lattice with } 380-400 \mu \mathrm{m} \text { strands } \\
\text { to generate porous structure. } 600 \\
\mu \mathrm{m} \text { pores with } 92.55 \% \text { porosity } \\
\text { and. Shifted patterns. }\end{array}$ & Compressive modulus: $\sim 22 \mathrm{MPa}$ & $\begin{array}{l}\text { A: Promotes cell attachment, proliferation and differentiation. } \\
\text { Increased cell attachment by shifted pattern structure. } \\
\text { D: Low compressive modulus. }\end{array}$ & [31] \\
\hline $\begin{array}{l}\text { Mesoporous bioactive } \\
\text { glass (MBG) + Alginate }\end{array}$ & $\begin{array}{l}\text { Human Bone } \\
\text { Marrow-derived } \\
\text { MSCs (hBMSC) }\end{array}$ & Bioplotter & Bone & $\begin{array}{l}8 \times 8 \times 8 \mathrm{~mm}^{3} \text { square lattice } \\
\text { scaffolds. } 50 \% \text { to } 67 \% \text { porosity. } \\
\text { Internal structure: micro- and } \\
\text { macro-pores with Nano channels } \\
\qquad(5 \mathrm{~nm}) .\end{array}$ & $\begin{array}{l}\text { Compressive strength: 0.4-1.6 MPa } \\
\text { Compressive modulus: 1.4-6 MPa } \\
\text { Shrinkage after drying at room temperature: } \\
\sim 30 \%\end{array}$ & $\begin{array}{l}\text { A: Good mechanical properties with improved cell attachment } \\
\text { compared to pure alginate only. Promotes cell proliferation } \\
\text { and differentiation. } \\
\text { Mechanical properties decrease after incubation with } \\
\text { simulated body fluid. }\end{array}$ & [18] \\
\hline $\begin{array}{c}\text { Collagen + Alginate + } \\
\text { Silica }\end{array}$ & $\begin{array}{l}\text { Mouse Pre- } \\
\text { Osteoblasts } \\
\text { (MC3T3-E1) }\end{array}$ & $\begin{array}{l}\text { Low } \\
\text { temperature } \\
\text { Bioplotter }\end{array}$ & Bone & $\begin{array}{l}\text { Multi-layered cylindrical struts } \\
(324-389 \mu \mathrm{m}) \text { with mesh-like } \\
\text { interconnected structure. Highly } \\
\text { porous }(>78 \%) \text { with } 468-481 \\
\mu \mathrm{m} \text { average pore size. }\end{array}$ & $\begin{array}{l}\text { Tensile Young's modulus: } 1.96 \pm 0.19 \mathrm{MPa} \\
\text { Max. tensile strength: } 0.12 \pm 0.03 \mathrm{MPa} \\
\text { Compressive Young's modulus: } \sim 0.2-0.3 \mathrm{MPa}\end{array}$ & $\begin{array}{l}\text { A: Biocompatibility, osteo-induction and production of bone- } \\
\text { like HA. Silica improved mechanical properties compared to } \\
\text { collagen + alginate hydrogels only. } \\
\text { D: 2-step scaffold fabrication and cell seeding, with >7-day } \\
\text { coating process that can cause blocked pores. }\end{array}$ & [11] \\
\hline $\begin{array}{l}\text { Silicon-doped Nano } \\
\text { Crystalline HA + PCL } \\
+ \text { Carbon Nanotubes } \\
\text { (CNT) }\end{array}$ & $\begin{array}{l}\text { Human } \\
\text { Osteosarcoma } \\
\text { (MG 63) }\end{array}$ & $\begin{array}{c}\text { Pneumatic } \\
\text { EnvisionTEC } \\
\text { 3D } \\
\text { Bioplotter® }\end{array}$ & Bone & $\begin{array}{l}\text { Multi-layered lattice. } 7 \text { layers } \\
\text { with } 6 \mathrm{~mm} \text { diameter and } 3 \mathrm{~mm} \\
\text { height. Interconnected square } \\
\quad 450-700 \text { um pores. }\end{array}$ & $\begin{array}{l}\text { Compressive strength: } \sim 4 \mathrm{MPa} \\
\text { Compressive elastic modulus: } 50 \mathrm{MPa}\end{array}$ & $\begin{array}{l}\text { A: CNTs improve cell attachment. } 2 \% \text { CNT scaffolds improve } \\
\text { mechanical properties and electrical conductivity. } \\
\text { D: Scaffolds loaded with more than } 2 \% \text { CNTs decrease } \\
\text { compressive resistance and porosity }(40 \%) \text {. }\end{array}$ & [9] \\
\hline GelMA & $\begin{array}{l}\text { MG63 } \\
\text { osteoblast-like } \\
\text { cells } \\
\text { Primary normal } \\
\text { human }\end{array}$ & $\begin{array}{l}\text { Customised } \\
\text { bioprinter }\end{array}$ & Bone & $\begin{array}{l}\text { Pores size } 400 \mu \mathrm{m} \text {, thickness } \\
750 \mu \mathrm{m} \\
\text { Hydrogel with } 8 \% \text { GelMA }\end{array}$ & $\begin{array}{l}\text { Before Crosslinking: storage modulus } 100 \mathrm{~Pa} \\
\text { After UV Crosslinking: storage modulus } 1000 \\
\mathrm{~Pa}\end{array}$ & $\begin{array}{l}\text { A: Storage modulus permits printing of the hydrogel before } \\
\text { crosslinking, and UV-crosslinking ensure suitable mechanical } \\
\text { properties to stimulate osteoblasts proliferation. GelMA } \\
\text { hydrogel has successfully been used to coat titanium. } \\
\text { D: Low cell viability }\end{array}$ & [32] \\
\hline
\end{tabular}




\begin{tabular}{|c|c|c|c|c|c|c|c|}
\hline & $\begin{array}{c}\text { osteoblasts } \\
\text { (NHOst) }\end{array}$ & & & & & & \\
\hline$\underset{\text { Beak }}{\text { PCL }+\underset{\text { PLGA }}{\text { Duck }}}$ & $\begin{array}{l}\text { New Zealand } \\
\text { White rabbit in } \\
\text { vivo study with } 5 \\
\text { mm critical } \\
\text { defects }\end{array}$ & $\begin{array}{l}\text { Bioprinting: } \\
\text { multi head } \\
\text { pneumatic } \\
\text { syringe } \\
\text { dispenser }\end{array}$ & Bone & $\begin{array}{c}3 \times 3 \times 20 \mathrm{~mm} \text { oblong scaffolds } \\
\text { with } 77.3 \% \text { porosity and } 2.787 \\
\mu \mathrm{m} \text { pores. }\end{array}$ & Compressive strength: $17 \mathrm{MPa}$ & $\begin{array}{l}\text { A: Promotes repair and de novo bone formation. High } \\
\text { compressive strength compared to PCL/ PLGA implanted } \\
\text { scaffolds. } \\
\text { D: Irregular scaffold shape and pore structure/ distribution. }\end{array}$ & [33] \\
\hline PLA+HA & $\begin{array}{l}\text { In vivo } \\
\text { implantation of } \\
\text { MSCs from New } \\
\text { Zealand Rabbits }\end{array}$ & $\begin{array}{c}\text { Desktop 3D } \\
\text { printer (Dot } \\
\text { Go 3D } \\
\text { Technology } \\
\text { Corporation, } \\
\text { Xiangtan, } \\
\text { China) }\end{array}$ & $\begin{array}{l}\text { Anterior Cruciate } \\
\text { Ligament }\end{array}$ & $\begin{array}{l}\text { Screw-like scaffold, } 10 \times 2.1 \mathrm{x} \\
2.1 \mathrm{~mm} \\
\text { Pores } \sim 290 \mu \mathrm{m}\end{array}$ & N/A & $\begin{array}{l}\text { A: In vivo work showed good bone/ graft interface and } \\
\text { successful tendon healing within bone tunnel. } \\
\text { D: No mechanical test and scaffold not representative of } \\
\text { physiological environment. }\end{array}$ & [34] \\
\hline
\end{tabular}

Table 1. Cell-free approach for bioprinting of musculoskeletal tissues. 


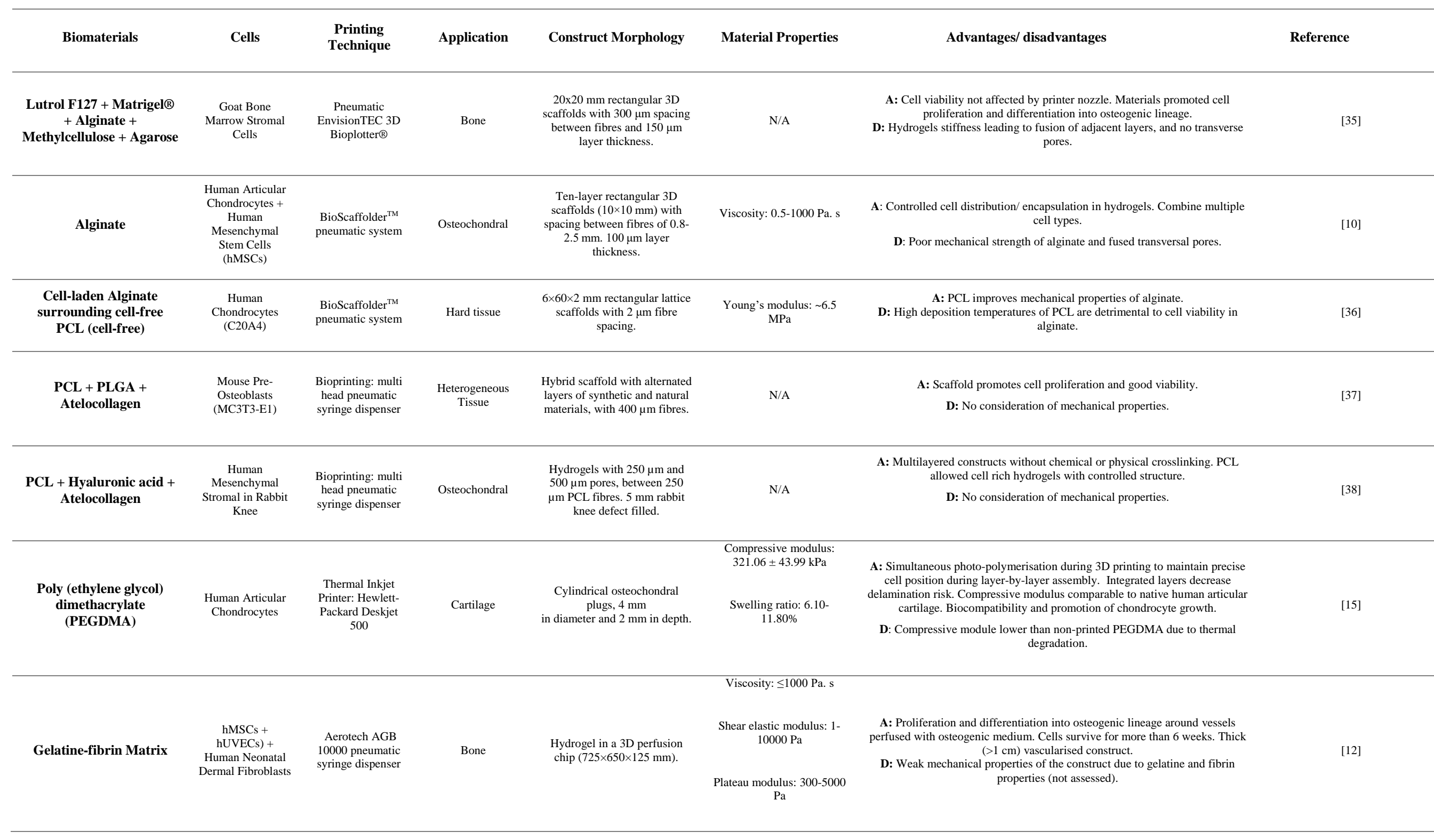




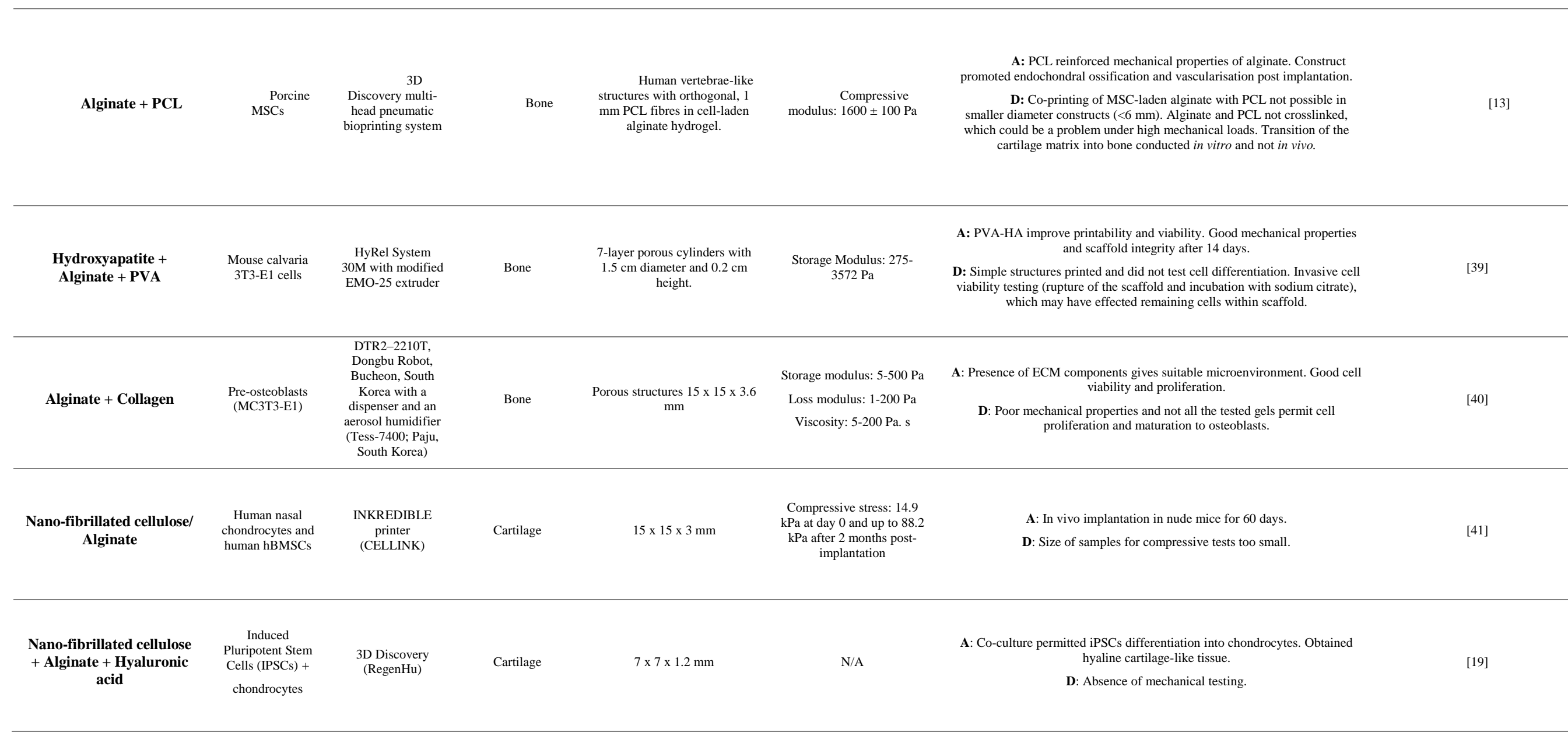




\begin{tabular}{|c|c|c|c|c|c|c|c|}
\hline $\begin{array}{l}\text { Gelatine/ Hyaluronic } \\
\text { acid/ Fibrinogen + PCL }\end{array}$ & $\begin{array}{l}\text { Mouse } \mathrm{C} 2 \mathrm{C} 12 \\
\text { myoblasts } \\
\text { 3T3 Fibroblasts } \\
\text { Scaffolds } \\
\text { implanted into } \\
\text { nude rats }\end{array}$ & $\begin{array}{l}\text { Integrated Tissue- } \\
\text { Organ Printer } \\
\text { (ITOP) }\end{array}$ & $\begin{array}{l}\text { Skeletal muscle } \\
\text { type II }\end{array}$ & $15 \times 5 \times 1 \mathrm{~mm}$ & $\begin{array}{l}\text { Compound muscle action } \\
\text { potential: } 3.6 \mathrm{mV}\end{array}$ & $\begin{array}{l}\text { A: Good cell viability and induced nerve integration. } \\
\text { D: Muscle function lower than positive control and did not investigate the } \\
\text { therapeutic efficacy. }\end{array}$ & [20] \\
\hline $\begin{array}{l}\text { Porcine tibialis anterior } \\
\text { muscle decellularised } \\
\text { ECM + PCL }\end{array}$ & $\begin{array}{c}\text { Mouse } \mathrm{C} 2 \mathrm{C} 12 \\
\text { myoblasts }\end{array}$ & $\begin{array}{l}\text { Integrated } \\
\text { composite } \\
\text { tissue/organ } \\
\text { building system } \\
\quad \text { (ICBS) }\end{array}$ & Skeletal muscle & $\begin{array}{l}\text { Parallel, diamond and chain } \\
\text { architectures }\end{array}$ & $\begin{array}{l}\text { Viscosity: shear thinning } \\
\text { from } 50 \text { to } 0.1 \text { Pa.s } \\
\text { Ultimate tensile stress: 2- } \\
\quad 3.5 \mathrm{KPa} \\
\text { Elastic modulus: } 9-12 \mathrm{KPa}\end{array}$ & $\begin{array}{l}\text { A: Good mechanical properties, structure and architecture compared to } \\
\text { collagen hydrogels widely used for tissue regeneration. The bioink provided a } \\
\text { suitable microenvironment for the cells. } \\
\text { D: No in vivo assessment. }\end{array}$ & [42] \\
\hline $\begin{array}{l}\text { Hyaluronic acid/ } \\
\text { Fibrinogen/ Gelatine + } \\
\text { Polyurethane (PU) or } \\
\text { PCL }\end{array}$ & $\begin{array}{l}\mathrm{C} 2 \mathrm{C} 12 \text { myoblasts } \\
\text { (with PU) and 3T3 } \\
\text { fibroblasts (with } \\
\text { PCL) }\end{array}$ & $\begin{array}{l}\text { Integrated Organ } \\
\text { Printer }\end{array}$ & $\begin{array}{l}\text { Muscle-tendon } \\
\text { unit }\end{array}$ & $\begin{array}{c}\text { Cross sections } 20 \times 5 \times 1 \mathrm{~mm} \\
10 \% \text { overlap region }\end{array}$ & $\begin{array}{l}\text { Young's modulus: } 45 \mathrm{MPa} \\
\text { for PCL part } \\
\text { Ultimate stress strain: } 4.5- \\
5.5 \mathrm{MPa} \text { for } 3 \mathrm{PCL} \\
\text { interface and PU part }\end{array}$ & $\begin{array}{l}\text { A: The scaffold was elastic in the muscle half and stiff on the tendon side. } \\
\text { D: Mechanical testing of the whole scaffold is missing. }\end{array}$ & [43] \\
\hline
\end{tabular}

Table 2. Cell-laden approach for bioprinting of musculoskeletal tissues. 


\section{Musculoskeletal bioinks and their characteristics}

Bioinks are an integral part of the bioprinting process. Most frequently, they are defined as hydrogel materials used for the encapsulation of cells in 3D bioprinting [44]. However, this definition is very limited and there are a number of examples where biological materials without cells are also termed as bioinks [45]. Opinion on the exact definition of bioink remains divided. From the literature it is clear that cell-only [46], cells with supporting materials (both synthetic and natural hydrogels) [13] and biomolecules without cells (BMP2) [47] are also referred to as bioinks.

In the musculoskeletal context, the scenario is even more complex. As seen from the literature review in the previous section, musculoskeletal tissues have been bioprinted using three approaches: cell-free, cell-laden and combination of both approaches (i.e. multimode printing of synthetic polymers, along with encapsulated cells). The definition of bioinks becomes even hazier as the commonly used definition of encapsulated cells within material becomes very limited in its scope and application. We anticipate that as bioprinting research advances through the development of both hardware (3D printers) and novel materials which support this process, the need for an accurate and more inclusive definition will become apparent. Here we will focus on the various bioink used for musculoskeletal applications as reported in literature and define the requirements for the fabrication of functional MSK tissues. Figure 8 shows physicalchemical, biological and fabrication requirements for musculoskeletal bioinks. Most of these requirements are similar to soft tissue bioprinting, however they become specific for musculoskeletal applications when additional mechanical stiffness and rigidity is required to fabricate structurally competent tissues. 


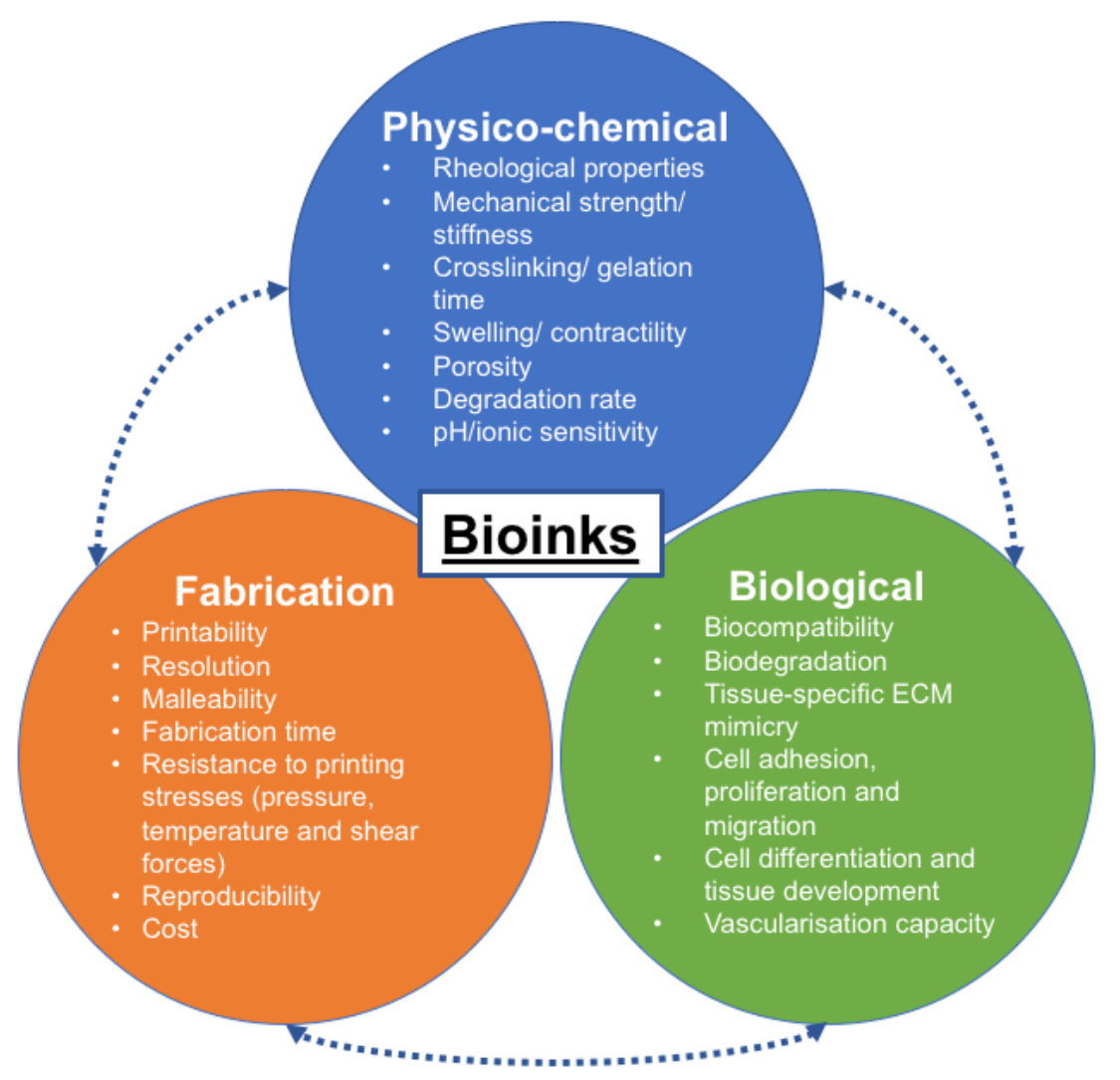

Figure 8. Characteristic requirements for bioinks in musculoskeletal tissue fabrication.

In the body, cells are found in highly organised environments, which are rich in water, nutrients and growth factors [48]**. Due to their significant water content, hydrogels have been identified as a primary material for bioprinting. Additionally, their hydrophilic nature allows hydrogels to retain large volumes of water without preventing a variety of crosslinking methods to be applied during fabrication of 3D networks [49]. In addition to this, hydrogels can be formulated to respond to various external stimuli such as temperature, electric or magnetic fields, light, pressure and sound vibrations before, during or after printing process [50]. Chemical factors including $\mathrm{pH}$, solvent composition, ionic strength and molecular species also affect hydrogel properties. Therefore a good understanding of these parameters on printability, stability in both in vitro and in vivo environments become essential.

Materials for bioprinting must be biocompatible and mimic natural cellular or tissue environment [51,52]. Specifically, materials used for cell encapsulation must mimic the natural environment of cells and it has been demonstrated that hydrogels based on extracellular matrix components permit this [53,54]. 
In terms of fabrication, printing materials should exhibit good printability and sufficient mechanical properties for cellular support and maintenance of the 3D structures [51]. For example, since highly viscous hydrogels are prone to clogging phenomena in the nozzles of extrusion-based printers, shear-thinning of some hydrogels, such as hyaluronic acid and peptide gels, can be advantageous $[55,56]$. However, it is important to adapt these hydrogels so they are able to 'self-heal' and maintain their printed structure once deposited [57]. Gelation time, along with the capacity to respond to physiological shear, tensile and compressive stresses, are other key parameters in bioprinting, which determine whether a printed construct can maintain its structure in a physiological environment $[58,59]$.

Hydrogels for bioprinting of musculoskeletal tissues can be classified as natural or synthetic depending on their origin [60], [61] and the most common ones used in the literature are summarised in Table 3.

Most natural hydrogels are based on components of the mammalian ECM, even though polymers from alternative sources such as algae are gaining interest [62]. Natural hydrogels show significant bioactivity compared to synthetic materials due to the intrinsic presence of biomolecules used for signalling, adhesion, biocompatibility and self-remodelling [2]. While bioactive components are important for cell growth and differentiation, the application of natural materials can lead to batch-to-batch variability, immunogenic reactions and disease transmission [63 $]^{* *}$. Interestingly, it has been observed that natural polymers such as hyaluronic acid, laminin, fibronectin and collagen are more susceptible to cell-driven biodegradation [64]. It is important to note that as well as individual components of the ECM, decellularised ECM has similarly been successfully utilised as bioinks in the printing of tissues analogues $[65,66]$. Tissue decellularised ECM can be obtained using chemical, physical, and biological treatments and provides an excellent representation of the natural ECM environment [67]. At the same time, decellularised ECM can lead to non-homogeneous cell seeding and immune reactions, if cellular components are not fully removed [67]. Furthermore, decellularisation treatments can damage the natural ECM and show poor mechanical properties in the material.

Synthetic materials are advantageous in terms of reproducibility and ease of processing compared to natural polymers. These polymers can sometimes lead to immunogenic reactions after partial degradation but this can be controlled and accelerated with the addition of matrix metalloproteinases, which show excellent biocompatibility $[68,69]$. Furthermore, synthetic materials can be tailored to form complexes with ECM proteins by covalent crosslinking. 
These covalently-bound molecules can be adhesion proteins or growth factors that enhance cell response within the hydrogels [58].

\begin{tabular}{|c|c|c|c|}
\hline Material & Description & Tissue & Reference \\
\hline \multicolumn{4}{|c|}{ Natural hydrogels } \\
\hline Alginate & $\begin{array}{l}\text { Polysaccharide derived from seaweed, which can be ionically crosslinked } \\
\text { with } \mathrm{CaCl}_{2} \text {. A: Fast gelation, general ease of use and low cost. D: Low } \\
\text { swelling properties can limit cell survival and growth in the long term, and } \\
\text { weak mechanical properties (Compressive modulus } \sim 10 \mathrm{KPa} \text { ). } \mathrm{CaCl}_{2} \\
\text { crosslinker can be cytotoxic at high concentrations. }\end{array}$ & Bone & {$[13,70]$} \\
\hline Chitosan & $\begin{array}{l}\text { Polysaccharide derived from chitin and most commonly obtained from the } \\
\text { exoskeletons of crustaceans. Commonly crosslinked using genipin or } \\
\text { glutaraldehyde. A: Good biocompatibility, biodegradability, anti- } \\
\text { inflammatory/ antibacterial properties, and good printability. Structure } \\
\text { similar to GAGs in cartilage. D: Slow gelation and weak mechanical } \\
\text { properties (Young's modulus in compressive mode for non-crosslinked } \\
\text { and genipin crosslinked films is } 38.7 \mathrm{KPa} \text { and } 87.3 \mathrm{KPa} \text { ). Glutaraldehyde } \\
\text { crosslinking is cytotoxic. }\end{array}$ & $\begin{array}{l}\text { Bone and } \\
\text { Cartilage }\end{array}$ & {$[71]$} \\
\hline Collagen & $\begin{array}{l}\text { Protein composed of glycine, praline and arginine to form tropocollagen } \\
\text { fibres of diameters ranging from } 50 \text { to } 200 \mathrm{~nm} \text {. A: Good swelling } \\
\text { properties and biocompatibility. D: Weak mechanical strength (mean peak } \\
\text { stress: } 0.76 \mathrm{MPa} \text { ), poor printability and expensive. }\end{array}$ & $\begin{array}{l}\text { Bone and } \\
\text { Cartilage }\end{array}$ & {$[72]$} \\
\hline Fibrin & $\begin{array}{l}\text { Fibrin is a non-globular protein present in the blood produced during blood } \\
\text { clotting. Can be enzymatically crosslinked. A: Good biocompatibility, } \\
\text { swelling and gelation properties. Good printability. D: Weak mechanical } \\
\text { properties and expensive. }\end{array}$ & Bone & {$[73]$} \\
\hline Gelatine & $\begin{array}{l}\text { Protein obtained from hydrolysed collagen, which can be crosslinked } \\
\text { using temperature and enzymes. A: Low cost, biocompatible, } \\
\text { biodegradable with high-cell adhesion. D: Poor printability. Often found } \\
\text { coupled to methyl acrylate (MA) to form GelMA (crosslinked with UV } \\
\text { light and harmful to cells), which has significantly increased mechanical } \\
\text { properties and improved printability compared to gelatine. }\end{array}$ & $\begin{array}{l}\text { Bone and } \\
\text { Cartilage }\end{array}$ & {$[74,75]$} \\
\hline $\begin{array}{l}\text { Hyaluronic } \\
\text { acid (HA) }\end{array}$ & $\begin{array}{l}\text { Polysaccharide and major component of ECM. (Photo) chemical } \\
\text { crosslinking. A: Good biocompatibility, good swelling ratio (0-45) fast } \\
\text { degradation rates ( } 100 \text { to } 0 \% \text { residual mass in } 8 \text { days). D: weak mechanical } \\
\text { properties (storage modulus } 400-1000 \mathrm{~Pa} \text {, loss modulus } 3-30 \mathrm{~Pa} \text { ) and } \\
\text { limited printability due to shear-thinning. }\end{array}$ & Bone & [76] \\
\hline dECM & $\begin{array}{l}\text { Tissue decellularized ECM can be obtained using chemical, physical, and } \\
\text { biological treatments. A: Representative of natural ECM environment, } \\
\text { tissue-specific, guides for stem cell differentiation and good } \\
\text { biocompatibility. D: Non-homogeneous cell seeding and immune } \\
\text { reactions if cellular components remain. Decellularization treatments can } \\
\text { damage natural ECM. Poor mechanical properties: max storage modulus } \\
\text { of } 300 \mathrm{~Pa} \text { and } 0-20 \mathrm{~Pa} \text { loss modulus. }\end{array}$ & $\begin{array}{l}\text { Skeletal } \\
\text { muscle }\end{array}$ & {$[42]$} \\
\hline \multicolumn{4}{|c|}{ Synthetic hydrogels } \\
\hline $\begin{array}{c}\text { Poly } \\
\text { ethylene } \\
\text { glycol (PEG) }\end{array}$ & $\begin{array}{l}\text { Synthetic polymer. Commonly crosslinked via chain-growth and step- } \\
\text { growth polymerisation, but can also be crosslinked using radiation and } \\
\text { other chemical/ physical methods. A: FDA approved and does not trigger } \\
\text { immunological responses. The material is soluble in water and organic } \\
\text { solvents, and has low protein adhesion properties. Good diffusion of }\end{array}$ & Bone & {$[17]$} \\
\hline
\end{tabular}




\begin{tabular}{|c|l|c|c|}
\hline & $\begin{array}{l}\text { nutrients and oxygen, and cell migration. When coupled to methyl } \\
\text { acrylate, it shows high swelling properties (swelling ratio from 37.88- } \\
100.93 \% \text { ) and good biocompatibility. Compressive modulus of 30-65 KPa } \\
\text { and 1.63-6.99 cP viscosity. Good printability. D: Often lack bioactive } \\
\text { molecules. }\end{array}$ & Bone & [78] \\
\hline $\begin{array}{c}\text { Self- } \\
\text { assembling } \\
\text { peptides }\end{array}$ & $\begin{array}{l}\text { Self-assembling peptide-based gels. A: Versatile properties that can be } \\
\text { easily tailored by adjusting chemicals and physical parameters. Good } \\
\text { extracellular matrix mimicry, while biocompatible and biodegradable. } \\
\text { Bioactive molecules can be incorporated. D: Peptide gels are degraded by } \\
\text { cellular proteolytic enzymes to cause shrinkage (20\% of hydrogel volume } \\
\text { in 12 days). Consequently, the mechanical properties become weaker } \\
\text { (decrease from 50 to 10 Pa in 12 days). }\end{array}$ & & \\
\hline
\end{tabular}

Table 3. Summary of the most popular hydrogels used for musculoskeletal bioprinting. Materials are categorised as natural or synthetic hydrogels, and the advantages (A) and disadvantages (D) of each material are described.

\section{Challenges in bioprinting of musculoskeletal tissues}

In addition to the hardware used for bioprinting, material availability and their selection are significant challenges and limitations for the success of bioprinting in musculoskeletal tissue fabrication. Materials/ bioinks composed of naturally derived materials are limited in their application due to batch to batch variability and often lack the mechanical strength required to mimic the in vivo environment of native musculoskeletal tissues [59]. In the literature, this issue is often resolved by combining the natural inks with stronger biocompatible materials, such as PCL, PLA and PLGA [28,33] as described previously.

Furthermore, bioinks are presently limited by their printability and resolution. Materials are often required to be viscous in order to maintain the morphology of printed structures and improve mechanical strength, but this can lead to blockages and unreliable material deposition. Importantly, this has adverse effects on the print quality and resolution, which can be detrimental to achieving the highly hierarchical structures in the tissues of the musculoskeletal system.

Tuneable, synthetic bioinks can provide a wide range of desirable properties, including controlled mechanics, degradation and printability. However, the techniques required to synthesise and crosslink these materials can cause cytotoxicity and prevent the ability to incorporate cells during the print process. For example, the monomers and photo initiators in some printable materials are toxic, but following UV crosslinking, the polymers formed are biocompatible and can support cell survival [79,80]. 
Further, printing of mechanically stable gelatine in the form of GelMA traditionally requires UV light during the print process and can damage cells. Recently, this challenge has been overcome by developing GelMA that can be crosslinked using visible light [81]. Crosslinking of natural bioinks can similarly be associated with cytotoxicity but this can often be alleviated by using low crosslinker concentrations or replacing with non-toxic analogues. For example, calcium chloride is used for crosslinking alginate, whereas glutaraldehyde is used for crosslinking collagen, gelatine, or chitosan. Calcium chloride is not toxic at low concentrations, while glutaraldehyde can be replaced with alternatives like genipin, during the crosslinking of collagen, gelatine and chitosan [82-84].

Hydrogels are the most utilised materials in bioprinting, due to their high-water content and parallels to native ECM. However, these biomaterials show poor mechanical properties so compromises must be made when considering characteristics such as composition, printability and mechanical strength. In the bioprinting of musculoskeletal tissues this has been overcome to an extent by incorporating multiple printing technologies at the same time. This approach permits deposition of materials with good mechanical properties and cell-laden bioinks, within a single engineered construct $[13,36]$.

Furthermore, the fundamental layer-by-layer nature of most printing techniques leads to difficulties in producing complex and hollow structures. This can be resolved by incorporating sacrificial materials for structural support during the fabrication process but this also increases the technological complexity, cost and time of the printing. Once the resolution, reproducibility, speed and customisation of current printing technologies have been defined and optimised, bioprinting can provide cost-effective and high-throughput systems for drug screening and tissue replacement. Importantly, robust methods for construct maturation and long-term maintenance, as well as quality control measures for bioprinted tissues, need to be considered in parallel with the technological advances of printers. Regulatory concerns, such as the ethics of stem cells and the use of Class II medical devices are also key factors to contemplate, for the success of bioprinting approach. Furthermore, at present there are no specific 3D bioprinting regulations defined by the Medicines and Healthcare Products Regulatory Agency (MHRA) in the UK or Food and Drug Administration (FDA) in the USA. 


\section{Summary and future perspective}

Printing of natural ECM-based materials embedded with cells provides significant advantages for tissue engineering, including biocompatibility, robust control of cell distribution and density within the scaffold. Nevertheless, traditionally materials have been produced and seeded with cells afterwards, and this can also be applied to printed constructs. In fact, this approach permits scaffolds with enhanced mechanical properties and resolution that natural materials often lack for musculoskeletal applications. Furthermore, co-printing of cell-laden and cell-free materials has been revealed to be beneficial for musculoskeletal tissue engineering applications [13,31,36]. All these approaches (cell-laden, cell-free and a combination of both) aim to obtain a complex, living tissue able to develop and mature, using the same fundamental technology.

The bioprinting literature suggests that the definition of bioinks remains unclear, considering various components such as cells, biomolecules, synthetic materials either alone or in combination, are defined as bioinks. Consensus in this matter is required. With the development of new bioinks in the future, nano-biofabrication of organs will become a reality and this will help to alleviate the increasing organ shortages worldwide. More specifically, technological advances in material science and engineering will permit versatility, nano-scale resolution and controllable distributing of cells and biomaterials, for a range of biomedical applications, including musculoskeletal repair.

The literature shows that bioprinting of muscles, tendons and ligaments is still a challenge, however promising progress has been made in bioprinting of bone and cartilage. Stiff materials have been combined with natural cell-laden hydrogels to form composite constructs that are mechanically stable with the ability to mimic the native ECM environment of osteochondral tissues. Further, it has been demonstrated that these scaffolds can be combined with stem cells to permit osteochondral development in vivo [13]. Progress has even been made in the bioprinting of vascularised bone [14]. Bio-sensors for bone formation [85], and protein and DNA arrays of stem cells $[86,87]$ have already been bioprinted, while next generation printable materials for controlling osteochondral cellular microenvironments are also in development. Nevertheless, these examples are all proof of concept studies and significant validation and development of next generation bioinks and their printing process is required in the future.

Fundamentally, the success of bioprinting in tissue engineering is heavily reliant on improvements in bioink properties, printing technologies, vascularisation of tissues, and controlled scaffold and cell maturation. Crucially for bone and cartilage applications it is 
important to improve the mechanical properties of bioinks and to maximise the resolution of the printed constructs. Innovative bioinks with benefits for musculoskeletal applications that are currently being developed include, dynamic switchable hydrogels with local variations in the density and size of collagen fibres throughout 3D tissues [88,89], and oxygen releasing biomaterials $[90,91]$.

In conclusion, bioprinting promises to be an important tool to fabricate complex tissue and organs. However, there are significant challenges to be resolved in terms of technological advances. Research to date has laid strong foundations and promise for the feasibility in manufacturing artificial organs, including musculoskeletal tissues. Bioprinting and the use of bioinks remain developing and expanding multidisciplinary fields of research with substantial potential for the future successes of tissue engineering and regenerative medicine.

\section{Executive Summary}

\section{Introduction}

- Successful translation of tissue engineering and regenerative medicine research relies on efficient, robust and cost-effective fabrication techniques.

- Bioprinting is an automated additive manufacturing process that permits the fabrication of 3D structures by selectively depositing biological materials layer-by-layer.

\section{Bioprinting and its role in musculoskeletal tissue fabrication}

- Bioprinting in the literature shows promise for musculoskeletal regeneration.

- Greater understanding of the native environment in tissues and organs, is required to maintain cell viability.

- Printer hardware needs to be developed to combine cell health with desired biomaterials characteristics.

\section{Musculoskeletal bioinks and their characteristics}

- Bioinks can be printable biological materials that must be compatible with the biological, chemical and physical requirements of native tissues.

- To be suitable for musculoskeletal applications, a bioink must have suitable mechanical strength for cellular support and maintenance in 3D structures.

- A range of natural and synthetic materials have been used for musculoskeletal applications.

- Natural materials provide the biological properties for tissue development but lack the mechanical strength of bone and cartilage. Synthetic materials provide a solution to this challenge but are less bioactive.

- The most promising examples in the literature, combine cell-free and cell-laden printing. 


\section{Challenges in bioprinting of musculoskeletal tissues}

- Bioinks cannot currently mimic the environments that cells experience in vivo.

- Printing living cells is challenging because there are multiple variables that need to be controlled and optimised when cells are combined with biomaterials.

- Hard tissues require mechanical strength that natural hydrogels often lack and synthetic materials can be detrimental to cell viability.

\section{Summary and future perspective}

- Bioinks must meet the following requirements: biocompatibility, biodegradability, good printability and sufficient mechanical strength for cellular support and maintenance of the 3D structures.

- The use of bioinks in bioprinting remains a developing and expanding multidisciplinary technology with substantial potential for the future successes of tissue engineering and regenerative medicine.

\section{References}

1. Wang XH, Ao Q, Tian XH et al. 3D Bioprinting Technologies for Hard Tissue and Organ Engineering. Materials, 9(10) (2016).

2. Malda J, Visser J, Melchels FP et al. 25th Anniversary Article: Engineering Hydrogels for Biofabrication. Advanced Materials, 25(36), 5011-5028 (2013).

3. Amini AA, Nair LS. Injectable hydrogels for bone and cartilage repair. Biomedical Materials, 7(2) (2012).

4. Yang G, Rothrauff BB, Tuan RS. Tendon and Ligament Regeneration and Repair: Clinical Relevance and Developmental Paradigm. Birth defects research. Part C, Embryo today : reviews, 99(3), 203-222 (2013).

5. Mielcarek M, Leisenring W, Torok-Storb B, Storb R. Graft-versus-host disease and donor-directed hemagglutinin titers after ABO-mismatched related and unrelated marrow allografts: Evidence for a graft-versusplasma cell effect. Blood, 96(3), 1150-1156 (2000).

6. Oryan A, Alidadi S, Moshiri A, Maffulli N. Bone regenerative medicine: classic options, novel strategies, and future directions. Journal of Orthopaedic Surgery and Research, 9 (2014).

7. Li J, Chen M, Fan X, Zhou H. Recent advances in bioprinting techniques: approaches, applications and future prospects. Journal of Translational Medicine, 14(1), 271 (2016).

8. Murphy SV, Atala A. 3D bioprinting of tissues and organs. Nature Biotechnology, 32(8), 773-785 (2014).

9. Goncalves EM, Oliveira FJ, Silva RF et al. Three-dimensional printed PCL-hydroxyapatite scaffolds filled with CNTs for bone cell growth stimulation. Journal of Biomedical Materials Research Part B-Applied Biomaterials, 104(6), 1210-1219 (2016). 
10. Fedorovich NE, Schuurman W, Wijnberg HM et al. Biofabrication of Osteochondral Tissue Equivalents by Printing Topologically Defined, Cell-Laden Hydrogel Scaffolds. Tissue Eng. Part C-Methods, 18(1), 33-44 (2012).

11. Lee H, Kim Y, Kim S, Kim G. Mineralized biomimetic collagen/alginate/silica composite scaffolds fabricated by a low-temperature bio-plotting process for hard tissue regeneration: fabrication, characterisation and in vitro cellular activities. Journal of Materials Chemistry B, 2(35), 5785-5798 (2014).

12. Kolesky DB, Homan KA, Skylar-Scott MA, Lewis JA. Three-dimensional bioprinting of thick vascularized tissues. Proceedings of the National Academy of Sciences of the United States of America, 113(12), 3179-3184 (2016).

13. Daly AC, Cunniffe GM, Sathy BN, Jeon O, Alsberg E, Kelly DJ. 3D Bioprinting of Developmentally Inspired Templates for Whole Bone Organ Engineering. Advanced Healthcare Materials, 5(18), 2353-2362 (2016).

14. Cui HT, Zhu W, Nowicki M, Zhou X, Khademhosseini A, Zhang LG. Hierarchical Fabrication of Engineered Vascularized Bone Biphasic Constructs via Dual 3D Bioprinting: Integrating Regional Bioactive Factors into Architectural Design. Advanced Healthcare Materials, 5(17), 2174-2181 (2016).

15. Cui XF, Breitenkamp K, Finn MG, Lotz M, D'Lima DD. Direct Human Cartilage Repair Using ThreeDimensional Bioprinting Technology. Tissue Eng. Part A, 18(11-12), 1304-1312 (2012).

16. Gao GF, Schilling AF, Hubbell K et al. Improved properties of bone and cartilage tissue from 3D inkjetbioprinted human mesenchymal stem cells by simultaneous deposition and photocrosslinking in PEG-GelMA. Biotechnology Letters, 37(11), 2349-2355 (2015).

17. Gao GF, Yonezawa T, Hubbell K, Dai GH, Cui XF. Inkjet-bioprinted acrylated peptides and PEG hydrogel with human mesenchymal stem cells promote robust bone and cartilage formation with minimal printhead clogging. Biotechnology Journal, 10(10), 1568-1577 (2015).

18. Luo YX, Wu CT, Lode A, Gelinsky M. Hierarchical mesoporous bioactive glass/alginate composite scaffolds fabricated by three-dimensional plotting for bone tissue engineering. Biofabrication, 5(1) (2013).

19. Nguyen D, Hagg DA, Forsman A et al. Cartilage Tissue Engineering by the 3D Bioprinting of iPS Cells in a Nanocellulose/Alginate Bioink. Scientific Reports, 7, 10 (2017).

20. Kang H-W, Lee SJ, Ko IK, Kengla C, Yoo JJ, Atala A. A 3D bioprinting system to produce human-scale tissue constructs with structural integrity. Nat Biotech, 34(3), 312-319 (2016).

21. Alshomer F, Chaves C, Serra T, Ahmed I, Kalaskar DM. Micropatterning of nanocomposite polymer scaffolds using sacrificial phosphate glass fibers for tendon tissue engineering applications. Nanomedicine: Nanotechnology, Biology and Medicine, 13(3), 1267-1277 (2017).

22. Lin R-Z, Chang H-Y. Recent advances in three-dimensional multicellular spheroid culture for biomedical research. Biotechnology Journal, 3(9-10), 1172-1184 (2008).

23. Jukes JM, Both SK, Leusink A, Sterk LMT, van Blitterswijk CA, de Boer J. Endochondral bone tissue engineering using embryonic stem cells. Proceedings of the National Academy of Sciences, 105(19), 6840-6845 (2008). 
24. Mackay AM, Beck SC, Murphy JM, Barry FP, Chichester CO, Pittenger MF. Chondrogenic differentiation of cultured human mesenchymal stem cells from marrow. Tissue Engineering, 4(4), 415-428 (1998).

25. Schon BS, Schrobback K, van der Ven M, Stroebel S, Hooper GJ, Woodfield TBF. Validation of a highthroughput microtissue fabrication process for 3D assembly of tissue engineered cartilage constructs. Cell and Tissue Research, 347(3), 629-642 (2012).

26. Mironov V, Visconti RP, Kasyanov V, Forgacs G, Drake CJ, Markwald RR. Organ printing: Tissue spheroids as building blocks. Biomaterials, 30(12), 2164-2174 (2009).

27. Chen H, Ozbolat IT, Asme. Development of a multi-arm bioprinter for hybrid tissue engineering. Proceedings of the Asme 8th International Manufacturing Science and Engineering Conference - 2013, Vol 1, 5 (2013).

28. Sherwood JK, Riley SL, Palazzolo R et al. A three-dimensional osteochondral composite scaffold for articular cartilage repair. Biomaterials, 23(24), 4739-4751 (2002).

29. Leukers B, Gulkan H, Irsen SH et al. Hydroxyapatite scaffolds for bone tissue engineering made by 3D printing. Journal of Materials Science-Materials in Medicine, 16(12), 1121-1124 (2005).

30. Ge ZG, Wang LS, Heng BC et al. Proliferation and Differentiation of Human Osteoblasts within 3D printed Poly-Lactic-co-Glycolic Acid Scaffolds. Journal of Biomaterials Applications, 23(6), 533-547 (2009).

31. Park SA, Lee SH, Kim WD. Fabrication of porous polycaprolactone/hydroxyapatite (PCL/HA) blend scaffolds using a 3D plotting system for bone tissue engineering. Bioprocess and Biosystems Engineering, 34(4), 505-513 (2011).

32. Christine M, Jasmin L, Michael O, Jennifer C, Andre S, Alexis FS-B. 3D bioprinting of GelMA scaffolds triggers mineral deposition by primary human osteoblasts. Biofabrication, 9(1), 015009 (2017).

33. Lee JY, Son SJ, Son JS, Kang SS, Choi SH. Bone-Healing Capacity of PCL/PLGA/Duck Beak Scaffold in Critical Bone Defects in a Rabbit Model. Biomed Research International, (2016).

34. Liu A, Xue G-h, Sun M et al. 3D Printing Surgical Implants at the clinic: A Experimental Study on Anterior Cruciate Ligament Reconstruction. Scientific reports, 6, 21704 (2016).

35. Fedorovich NE, Dewijn JR, Verbout AJ, Alblas J, Dhert WJA. Three-dimensional fiber deposition of cell-laden, viable, patterned constructs for bone tissue printing. Tissue Eng. Part A, 14(1), 127-133 (2008).

36. Schuurman W, Khristov V, Pot MW, van Weeren PR, Dhert WJA, Malda J. Bioprinting of hybrid tissue constructs with tailorable mechanical properties. Biofabrication, 3(2), 7 (2011).

37. Shim JH, Kim JY, Park M, Park J, Cho DW. Development of a hybrid scaffold with synthetic biomaterials and hydrogel using solid freeform fabrication technology. Biofabrication, 3(3) (2011).

38. Shim JH, Jang KM, Hahn SK et al. Three-dimensional bioprinting of multilayered constructs containing human mesenchymal stromal cells for osteochondral tissue regeneration in the rabbit knee joint. Biofabrication, 8(1) (2016). 
39. Bendtsen ST, Quinnell SP, Wei M. Development of a novel alginate-polyvinyl alcohol-hydroxyapatite hydrogel for 3D bioprinting bone tissue engineered scaffolds. Journal of Biomedical Materials Research Part A, n/a-n/a (2017).

40. Lee HJ, Kim YB, Ahn SH et al. A New Approach for Fabricating Collagen/ECM-Based Bioinks Using Preosteoblasts and Human Adipose Stem Cells. Advanced Healthcare Materials, 4(9), 1359-1368 (2015).

41. Möller T, Amoroso M, Hägg D et al. In Vivo Chondrogenesis in 3D Bioprinted Human Cell-laden Hydrogel Constructs. Plastic and Reconstructive Surgery Global Open, 5(2), e1227 (2017).

42. Choi Y-J, Kim TG, Jeong J et al. 3D Cell Printing of Functional Skeletal Muscle Constructs Using Skeletal Muscle-Derived Bioink. Advanced Healthcare Materials, 5(20), 2636-2645 (2016).

43. Tyler KM, Morgan B, Young-Joon S et al. A 3D bioprinted complex structure for engineering the muscle-tendon unit. Biofabrication, 7(3), 035003 (2015).

44. Li JP, Chen MJ, Fan XQ, Zhou HF. Recent advances in bioprinting techniques: approaches, applications and future prospects. Journal of Translational Medicine, 14 (2016).

45. Dababneh AB, Ozbolat IT. Bioprinting Technology: A Current State-of-the-Art Review. Journal of Manufacturing Science and Engineering-Transactions of the Asme, 136(6) (2014).

46. Kasza KE, Rowat AC, Liu J et al. The cell as a material. Current Opinion in Cell Biology, 19(1), 101107 (2007).

47. Cooper GM, Miller ED, DeCesare GE et al. Inkjet-Based Biopatterning of Bone Morphogenetic Protein2 to Spatially Control Calvarial Bone Formation. Tissue Eng Part A, 16(5), 1749-1759 (2010).

48. Murphy WL, McDevitt TC, Engler AJ. Materials as stem cell regulators. Nature Materials, 13(6), 547557 (2014).

49. Muller M, Becher J, Schnabelrauch M, Zenobi-Wong M. Nanostructured Pluronic hydrogels as bioinks for 3D bioprinting. Biofabrication, 7(3) (2015).

50. Jacob RS, Ghosh D, Singh PK et al. Self healing hydrogels composed of amyloid nano fibrils for cell culture and stem cell differentiation. Biomaterials, 54, 97-105 (2015).

51. He Y, Yang FF, Zhao HM, Gao Q, Xia B, Fu JZ. Research on the printability of hydrogels in 3D bioprinting. Scientific Reports, 6 (2016).

52. Bertassoni LE, Cecconi M, Manoharan V et al. Hydrogel bioprinted microchannel networks for vascularization of tissue engineering constructs. Lab on a Chip, 14(13), 2202-2211 (2014).

53. Geckil H, Xu F, Zhang XH, Moon S, Demirci U. Engineering hydrogels as extracellular matrix mimics. Nanomedicine, 5(3), 469-484 (2010).

54. Wang XF, Song Y, Liu YS et al. Osteogenic Differentiation of Three-Dimensional Bioprinted Constructs Consisting of Human Adipose-Derived Stem Cells In Vitro and In Vivo. Plos One, 11(6) (2016). 
55. Schneider JP, Pochan DJ, Ozbas B, Rajagopal K, Pakstis L, Kretsinger J. Responsive hydrogels from the intramolecular folding and self-assembly of a designed peptide. Journal of the American Chemical Society, 124(50), 15030-15037 (2002).

56. Haines-Butterick L, Rajagopal K, Branco M et al. Controlling hydrogelation kinetics by peptide design for three-dimensional encapsulation and injectable delivery of cells. Proceedings of the National Academy of Sciences of the United States of America, 104(19), 7791-7796 (2007).

57. Ouyang LL, Highley CB, Rodell CB, Sun W, Burdick JA. 3D Printing of Shear-Thinning Hyaluronic Acid Hydrogels with Secondary Cross-Linking. ACS Biomater. Sci. Eng., 2(10), 1743-1751 (2016).

58. Nur-E-Kamal A, Ahmed I, Kamal J, Babu AN, Schindler M, Meiners S. Covalently attached FGF-2 to three-dimensional polyamide nanofibrillar surfaces demonstrates enhanced biological stability and activity. Molecular and Cellular Biochemistry, 309(1-2), 157-166 (2008).

59. Akhmanova M, Osidak E, Domogatsky S, Rodin S, Domogatskaya A. Physical, Spatial, and Molecular Aspects of Extracellular Matrix of In Vivo Niches and Artificial Scaffolds Relevant to Stem Cells Research. Stem Cells International, (2015).

60. Loo YH, Hauser CAE. Bioprinting synthetic self-assembling peptide hydrogels for biomedical applications. Biomedical Materials, 11(1) (2016).

61. Billiet T, Vandenhaute M, Schelfhout J, Van Vlierberghe S, Dubruel P. A review of trends and limitations in hydrogel-rapid prototyping for tissue engineering. Biomaterials, 33(26), 6020-6041 (2012).

62. Jia J, Richards DJ, Pollard S et al. Engineering alginate as bioink for bioprinting. Acta Biomaterialia, 10(10), 4323-4331 (2014).

63. Stanton MM, Samitier J, Sanchez S. Bioprinting of 3D hydrogels. Lab on a Chip, 15(15), 3111-3115 (2015).

64. Hubbell JA. Materials as morphogenetic guides in tissue engineering. Current Opinion in Biotechnology, 14(5), 551-558 (2003).

65. Pati F, Jang J, Ha DH et al. Printing three-dimensional tissue analogues with decellularized extracellular matrix bioink. Nature Communications, 5 (2014).

66. Skardal A, Devarasetty M, Kang HW et al. A hydrogel bioink toolkit for mimicking native tissue biochemical and mechanical properties in bioprinted tissue constructs. Acta Biomaterialia, 25, 24-34 (2015).

67. Kumar A, Nune KC, Misra RDK. Biological functionality of extracellular matrix-ornamented threedimensional printed hydroxyapatite scaffolds. Journal of Biomedical Materials Research Part A, 104(6), 13431351 (2016).

68. Woessner JF. Matrix metalloproteinases and their inhibitors in connective-tissue remodeling. Faseb Journal, 5(8), 2145-2154 (1991).

69. Kapoor C, Vaidya S, Wadhwan V, Hitesh, Kaur G, Pathak A. Seesaw of matrix metalloproteinases (MMPs). Journal of Cancer Research and Therapeutics, 12(1), 28-35 (2016). 
70. Fedorovich NE, Kuipers E, Gawlitta D, Dhert WJA, Alblas J. Scaffold Porosity and Oxygenation of Printed Hydrogel Constructs Affect Functionality of Embedded Osteogenic Progenitors. Tissue Eng. Part A, 17(19-20), 2473-2486 (2011).

71. Muzzarelli RAA, Mehtedi M, Bottegoni C, Aquili A, Gigante A. Genipin-Crosslinked Chitosan Gels and Scaffolds for Tissue Engineering and Regeneration of Cartilage and Bone. Marine Drugs, 13(12), 7314-7338 (2015)

72. Van Vlierberghe S, Dubruel P, Schacht E. Biopolymer-Based Hydrogels As Scaffolds for Tissue Engineering Applications: A Review. Biomacromolecules, 12(5), 1387-1408 (2011).

73. Koob S, Torio-Padron N, Stark GB, Hannig C, Stankovic Z, Finkenzeller G. Bone Formation and Neovascularization Mediated by Mesenchymal Stem Cells and Endothelial Cells in Critical-Sized Calvarial Defects. Tissue Eng. Part A, 17(3-4), 311-321 (2011).

74. Petrenko YA, Ivanov RV, Petrenko AY, Lozinsky VI. Coupling of gelatin to inner surfaces of pore walls in spongy alginate-based scaffolds facilitates the adhesion, growth and differentiation of human bone marrow mesenchymal stromal cells. Journal of Materials Science-Materials in Medicine, 22(6), 1529-1540 (2011).

75. Katsen-Globa A, Meiser I, Petrenko YA et al. Towards ready-to-use 3-D scaffolds for regenerative medicine: adhesion-based cryopreservation of human mesenchymal stem cells attached and spread within alginate-gelatin cryogel scaffolds. Journal of Materials Science-Materials in Medicine, 25(3), 857-871 (2014).

76. Cui N, Qian JM, Liu T, Zhao N, Wang HJ. Hyaluronic acid hydrogel scaffolds with a triple degradation behavior for bone tissue engineering. Carbohydrate Polymers, 126, 192-198 (2015).

77. Sawkins MJ, Bowen W, Dhadda P et al. Hydrogels derived from demineralized and decellularized bone extracellular matrix. Acta Biomaterialia, 9(8), 7865-7873 (2013).

78. Castillo Diaz LA, Elsawy M, Saiani A, Gough JE, Miller AF. Osteogenic differentiation of human mesenchymal stem cells promotes mineralization within a biodegradable peptide hydrogel. Journal of Tissue Engineering, 7, 2041731416649789 (2016).

79. Van Landuyt KL, Krifka S, Hiller KA et al. Evaluation of cell responses toward adhesives with different photoinitiating systems. Dental Materials, 31(8), 916-927 (2015).

80. Kim SH, Chu CC. Fabrication of a Biodegradable Polysaccharide Hydrogel With Riboflavin, Vitamin B2, as a Photo-Initiator and L-Arginine as Coinitiator Upon UV Irradiation. Journal of Biomedical Materials Research Part B-Applied Biomaterials, 91B(1), 390-400 (2009).

81. Wang ZJ, Abdulla R, Parker B, Samanipour R, Ghosh S, Kim K. A simple and high-resolution stereolithography-based 3D bioprinting system using visible light crosslinkable bioinks. Biofabrication, 7(4) (2015).

82. Butler MF, Ng YF, Pudney PDA. Mechanism and kinetics of the crosslinking reaction between biopolymers containing primary amine groups and genipin. Journal of Polymer Science Part a-Polymer Chemistry, 41(24), 3941-3953 (2003).

83. Bigi A, Cojazzi G, Panzavolta S, Roveri N, Rubini K. Stabilization of gelatin films by crosslinking with genipin. Biomaterials, 23(24), 4827-4832 (2002). 
84. Muzzarelli RAA. Genipin-crosslinked chitosan hydrogels as biomedical and pharmaceutical aids. Carbohydrate Polymers, 77(1), 1-9 (2009).

85. Lee J, Bubar CT, Busnaina A, Shefelbine SJ, Lee H. Standardization of a bone formation biomarker quantification using screen printed electrodes. Applied Spectroscopy Reviews, 51(7-9), 753-761 (2016).

86. Wilson WC, Boland T. Cell and organ printing 1: Protein and cell printers. Anatomical Record Part aDiscoveries in Molecular Cellular and Evolutionary Biology, 272A(2), 491-496 (2003).

87. Sakurai K, Teramura Y, Iwata H. Cells immobilized on patterns printed in DNA by an inkjet printer. Biomaterials, 32(14), 3596-3602 (2011).

88. Gillette BM, Jensen JA, Tang BX et al. In situ collagen assembly for integrating microfabricated threedimensional cell-seeded matrices. Nature Materials, 7(8), 636-640 (2008).

89. Gillette BM, Rossen NS, Das N et al. Engineering extracellular matrix structure in 3D multiphase tissues. Biomaterials, 32(32), 8067-8076 (2011).

90. Craig RA, McCoy CP, De Baroid AT, Andrews GP, Gorman SP, Jones DS. Quantification of singlet oxygen generation from photodynamic hydrogels. Reactive \& Functional Polymers, 87, 1-6 (2015).

91. Harrison BS, Eberli D, Lee SJ, Atala A, Yoo JJ. Oxygen producing biomaterials for tissue regeneration. Biomaterials, 28(31), 4628-4634 (2007). 